\title{
Jumlah Sel Piramidal CA3 Hipokampus Tikus Putih Jantan pada Berbagai Model Stres Kerja Kronik
}

\author{
Fitranto Arjadi, ${ }^{1}$ Sri Kadarsih Soejono, ${ }^{2}$ Lientje Setyawati Maurits, ${ }^{3,}$ Mulyoto Pangestu ${ }^{4}$ \\ ${ }^{1}$ Lab. Anatomi, Jurusan Kedokteran Fakultas Kedokteran dan Ilmu Kesehatan Universitas Jenderal \\ Soedirman, ${ }^{2}$ Lab. Fisiologi Fakutas Kedokteran Universitas Gadjah Mada, ${ }^{3}$ Lab. Ilmu Kesehatan \\ Kerja Fakutas Kedokteran Universitas Gadjah Mada, ${ }^{4}$ Reproduction and Development, Departement \\ Obstetric and Gynaecology Monash University
}

\begin{abstract}
Abstrak
Paparan stres kronik dan berkepanjangan mengakibatkan hilangnya neuron di regio CA3 (cornu ammonis) hipokampus dan penurunan kognitif. Tujuan penelitian mengetahui perbedaan jumlah sel piramidal CA3 hipokampus tikus putih jantan pada model stres kerja meliputi paradoxical sleep deprivation (PSD), imobilisasi, dan footshock kronik. Metode penelitian adalah post-test only with control group design experimental dengan rancangan acak lengkap menggunakan 24 ekor tikus putih jantan galur Wistar usia 3-4 bulan yang dibagi 4 kelompok: KI kontrol tanpa perlakuan, KII (stres PSD), KIII (stres imobilisasi), dan KIV (stres footshock) dan sel piramidal CA3 hipokampus diwarnai dengan toluidine-blue. Jumlah sel dihitung menggunakan perangkat lunak Image raster v2.1, perbesaran 400x tiap 10 lapangan pandang. Penelitian dilakukan 6 bulan (April-September 2012) di Laboratorium Hewan Coba, Fakultas Kedokteran dan Ilmu Kesehatan Universitas Jenderal Soedirman. Analisis data menggunakan analysis of variance (ANOVA) dengan Post-Hoc least significant difference (LSD) menunjukkan perbedaan jumlah sel piramidal CA3 hipokampus signifikan $(\mathrm{p}=0,037)$ pada minimal dua kelompok perlakuan. Uji statistik dengan Post-Hoc LSD menunjukkan perbedaan signifikan jumlah sel piramidal CA3 hipokampus antara kelompok kontrol $(12,9 \pm 2,47)$ dan kelompok imobilisasi $(9,00 \pm 1,53)(p<0,05)$. Simpulan, kelompok imobilisasi kronik memiliki jumlah sel piramidal CA3 hipokampus terendah dibandingkan dengan ketiga kelompok lainnya. [MKB. 2014;46(4):197-202]
\end{abstract}

Kata kunci: Model stres kerja kronik, sel piramidal CA3 hipokampus, tikus putih jantan

\section{Number of CA3 Pyramidal Cell in Male Albino Rat Hippocampus Exposed to Various Chronic Work Stress Models}

\begin{abstract}
Prolonged and chronic exposure to stress leads to the loss of neurons at the CA3 (cornu ammonis) hippocampus region and spatial memory deficits. The aim of this study was to study the number of CA3 pyramidal cells in albino rats that were exposed to chronic stress of works model consisting of paradoxical sleep deprivation (PSD), immobilization, and foot shock stresses. The method applied was the post-test only method with control group experimental design using completed randomized design (CRD on 24 3-4 month old male Wistar rats . The rats were divided into 4 groups: group I (control), group II (PSD stress), group III (immobilization stress), and group IV (footshock stress). The CA3 pyramidal cell hippocampus was stained with toluidine-blue. The number of CA3 pyramidal cell of hippocampus was counted using Image raster v2.1 software at 400x magnification in 10 duplicates for each sample. The study was conducted in six months (April-September 2012) at the Animal Laboratory, Faculty of Medical and Health Sciences, Jenderal Soedirman University. Analysis for the differences in the number of CA3 pyramidal cells was conducted using analysis of variance (ANOVA) with Post-Hoc LSD. The results of the ANOVA showed a $p$ value $=0.037$, meaning that there was significant difference in at least two groupsof treatment. Further statistical test using Post-Hoc LSD showed a significant difference between the control group $(12.9 \pm 2.47)$ and the chronic immobillization group $(9,00 \pm 1,53)(p<0.05)$. In conclusion, the chronic immobillization stress group has the lowest average number of hippocampus CA3 pyramidal cells compared to other groups. [MKB. 2014;46(4):197-202]
\end{abstract}

Key words: CA3 pyramidal cell in hippocampus, chronic works stress model, male albino rats

Korespondensi: Fitrianto Arjadi, dr., M.Kes, Lab. Anatomi, Jurusan Kedokteran Fakultas Kedokteran dan Ilmu Kesehatan Universitas Jenderal Soedirman, Jalan dr. Gumbreg No 1 Purwokerto 53146, mobile 08156996806, e-mail f.arjadi@yahoo.com 


\section{Pendahuluan}

Hipokampus adalah bagian sistem limbik yang berperan dalam belajar, mengingat, pengaturan emosi, serta hipotalamus. ${ }^{1}$ Sel di hipokampus berbentuk piramidal yang berbeda di setiap regio cornu ammonis (CA) meliputi CA1, CA2, dan $\mathrm{CA} 3$. Regio CA3 sel piramidal adalah regio yang paling luas dengan badan sel piramidal besar dan ovoid tetapi kurang padat. ${ }^{2}$ Sel piramidal di regio $\mathrm{CA} 1$ dan juga $\mathrm{CA} 2$ paling rentan terhadap hipoksia, sedangkan regio $\mathrm{CA} 3$ rentan terhadap pengaruh stressor fisik dan juga paparan stres kronik pada hipokampus yang mengakibatkan depresi dan hilangnya neuron di hipokampus serta amigdala yang selanjutnya menurunkan fungsi ingatan dan kognitif. ${ }^{3}$ Stres itu memengaruhi sumbu hipotalamus-hipofisis-adrenal (HHA), menghasilkan glukokortikoid dan apabila terjadi pengaruh yang berbahaya dari glukokortikoid yang berlebihan, maka terjadi umpan balik negatif pada reseptor glukokortikoid untuk menghambat aktivitas sumbu HHA. Pada keadaan stres kronik, sinyal umpan balik lemah dan sistem tersebut tetap aktif dalam periode waktu lama sehingga mengakibatkan efek yang merusak bagi tubuh, termasuk pada hipokampus. ${ }^{5}$

Penelitian model stres kerja kronik terhadap hewan coba dilaksanakan untuk memperlihatkan hormon glukokortikoid yang disekresikan selama stres sebagai neurotoksik bagi hipokampus dan berakhir dengan kematian neuron. ${ }^{4}$ Stres pada dunia kerja disebabkan oleh kondisi dan situasi pekerjaan, status pekerjaan dan karir yang tidak jelas, dan hubungan interpersonal serta dapat mengakibatkan terganggunya kesehatan fisik, kesehatan psikologis, memori, dan memengaruhi individu dalam pengambilan keputusan. Stres kerja tipe kronik terjadi jika berlangsung secara intermiten dalam jangka panjang serta terjadi berkesinambungan. ${ }^{6}$

Pada tikus, stres kerja model paradoxical sleep deprivation (PSD) adalah metode yang dianalogikan dengan stres pada manusia akibat pengurangan waktu tidur sebagai bentuk stressor fisik dan juga psikologi, ${ }^{7}$ mampu menurunkan potensiasi jangka panjang di CA1 hipokampus. ${ }^{8}$ Stres imobilisasi dianalogikan sebagai pola sedentarian mewakili stressor psikologis, fisik, dan sosial ${ }^{7}$ mampu menyebabkan depresi yang mengakibatkan hilangnya neuron hipokampus. ${ }^{9}$ Stres footshock pada tikus adalah stressor fisik yang dapat dianalogikan sebagai stres fisik pada manusia $^{7}$ mampu meningkatkan indeks apoptosis neuron hipokampus regio $\mathrm{CA} 3$, perubahan fungsi, dan struktur hipokampus. ${ }^{3}$

\section{Metode}

Metode penelitian adalah eksperimental post test only with control group design selama 25 hari menggunakan rancangan acak lengkap (RAL). Prosedur acak lengkap tersebut dilakukan dengan cara memberi nomor pada tikus dengan angka 1-28, kemudian menentukan kelompok kontrol (K1) dengan angka 1-7, kelompok perlakuan PSD (K2) dengan angka 8-14, kelompok perlakuan imobilisasi (K3) dengan angka 15-21, dan juga kelompok perlakuan footshock (K4) dengan angka 22-28. Prosedur selanjutnya adalah menjatuhkan pensil untuk menentukan awal pembacaan tabel randomisasi dan menentukan kelompok kontrol dan perlakuan dengan cara mengambil 2 angka terakhir dari tabel randomisasi yang digunakan sebagai acuan pengelompokan kelompok kontrol dan perlakuan.

Hewan coba adalah berupa tikus putih (Rattus norvegicus) jantan galur Wistar berjumlah 24 ekor usia 3-4 bulan, dengan bobot badan 200300 gram dan dibagi menjadi 4 kelompok, yaitu kelompok I; dibiarkan bebas dalam kandang dan pola tidur yang normal, kelompok II; model stres PSD menggunakan modified multiple platform method, 18 jam sehari jam 04.00 sampai $22.00,{ }^{10}$ kelompok III; perlakuan model stres imobilisasi menggunakan silinder transparan ukuran panjang $21 \mathrm{~cm}$ diameter $6 \mathrm{~cm}, 1$ jam sehari pukul 09.00 $-10.00,{ }^{11}$ kelompok IV; perlakuan model stres footshock menggunakan kotak akrilik ukuran $14 \times 25 \times 28 \mathrm{~cm}$ dengan dasar dialiri listrik, disengat dengan intensitas $5 \mathrm{~mA}$ selama 0,1 detik, 1 jam sehari masing-masing 4-6 kali renjatan pukul $09.00-10.00 .^{12}$

Pengukuran bobot badan (BB) hewan coba dilakukan pada awal dan akhir penelitian untuk mengorfirmasi apakah terdapat perubahan bobot badan tikus putih. Hewan coba diterminasi pada hari ke-26 dengan inhalasi eter dan diambil organ otak. Otak dibilas larutan $\mathrm{NaCl}$ fisiologis, difiksasi dalam larutan Boein dan diwarnai toluidine-blue. Jumlah pada sel piramidal CA3 hipokampus dapat dihitung menggunakan perangkat lunak Image raster v2.1, pada perbesaran $400 \mathrm{x}$, lalu dihitung 10 lapang pandang per preparat berdasarkan terdapat inti sel. Analisis perbedaan bobot badan tikus sebelum dengan sesudah perlakuan diuji menggunakan paired T-test, jumlah sel piramidal CA3 hipokampus menggunakan uji one way analisis varian (ANOVA) dan dilanjutkan dengan post-hoc LSD test dengan tingkat kepercayaan $95 \%(\alpha=0,05))^{7}$ Penelitian dilakukan selama 6 bulan, periode April sampai September 2012 di Laboratorium Hewan Coba, FKIK, Universitas 
Tabel 1 Bobot Badan Tikus Sebelum dan Sesudah Perlakuan

\begin{tabular}{lccc}
\hline \multicolumn{1}{c}{ Kelompok } & E Sampel & BB Rata-rata Awal (gram) & BB Rata-rata Akhir (gram) \\
\hline I (kontrol) & 6 & $316,67 \pm 43,78$ & $395,83 \pm 33,23^{*}$ \\
II (PSD) & 6 & $295,83 \pm 29,23$ & $283,33 \pm 49,16$ \\
III (imobilisasi) & 6 & $225,00 \pm 31,62$ & $245,83 \pm 36,79$ \\
IV (footshock) & 6 & $270,83 \pm 18,82$ & $266,67 \pm 20,41$ \\
\hline
\end{tabular}

Keterangan: $*=\mathrm{p}<0,05$ berbeda secara signifikan pada uji paired T-test

Soedirman sedangkan pada pembuatan preparat dilakukan di Laboratorium Patologi Anatomi, FK UGM. Etika penelitian didapatkan dari Komisi Etik Penelitian Kedokteran dan Kesehatan FK UGM.

\section{Hasil}

Data bobot badan tikus sebelum dan sesudah pemberian perlakuan dapat diamati pada Tabel 1 . Data bobot badan diuji normalitas Shapiro-Wilk dan hasilnya menunjukkan data terdistribusi normal $(\mathrm{p}>0,05)$ pada setiap kelompok dan paired t-test (Tabel 1) memperlihatkan pada kelompok I terdapat peningkatan BB tikus secara signifikan $(p<0,05)$ sebesar 79,2 gram, sedangkan pada kelompok III terdapat peningkatan BB sebesar 20,8 gram, namun secara statistik tidak signifikan. Kelompok II dan juga kelompok IV mengalami penurunan BB secara tidak signifikan ( $>0,05)$ sebesar 12,5 gram dan 4,2 gram. Hasil pengamatan berupa jumlah sel piramidal CA3 hipokampus pada masing-masing kelompok dan dapat dilihat pada Gambar 1 .

Hasil uji ANOVA menunjukkan perbedaan jumlah sel piramidal CA3 hipokampus signifikan $(\mathrm{p}=0,037)$ pada minimal dua kelompok perlakuan. Analisis post-hoc LSD menunjukkan perbedaan yang signifikan $(\mathrm{p}=0,005)$ terletak pada kelompok kontrol dan kelompok perlakuan imobilisasi.

Tabel 2 Jumlah Sel Piramidal CA3 Hipokampus

\begin{tabular}{lcc}
\hline \multicolumn{1}{c}{ Kelompok } & $\sum$ Sampel & $\begin{array}{c}\text { Jumlah Sel } \\
\text { Piramidal }\end{array}$ \\
\hline I (kontrol) & 6 & $12,90 \pm 2,47$ \\
II (PSD) & 6 & $10,48 \pm 1,19$ \\
III (imobilisasi) & 6 & $09,00 \pm 1,53 *$ \\
IV (footshock) & 6 & $10,67 \pm 2,87$ \\
\hline Keterangan: *berbeda secara signifikan $(\mathrm{p}<0,05)$ dengan \\
\multicolumn{3}{c}{ kelompok I }
\end{tabular}

\section{Pembahasan}

Pada kelompok kontrol, peningkatan BB badan tikus signifikan $(p<0,05)$ disebabkan mendapatkan pola tidur yang normal, makanan dan minuman yang cukup, serta tidak mendapatkan perlakuan stres apa pun. Bobot badan yang meningkat sesuai dengan pertambahan umur menunjukkan pertumbuhan normal. Pada kelompok dengan stres PSD kronik yang mengaktivasi sumbu-HHA dan penurunan BB sampai $14 \%$ meskipun diberi banyak asupan makanan. ${ }^{7}$ Model stres footshock diketahui merupakan stressor ekstrem yang dapat menyebabkan penurunan asupan makanan dan bobot badan hewan coba akibat kelelahan fisik yang ditandai dengan ada hiperfagia, penurunan bobot badan, dan peningkatan katekolamin. ${ }^{13}$

Secara umum stres itu memengaruhi nafsu makan, akan tetapi respons stres tersebut terhadap perubahan bobot badan pada hewan coba hasilnya dapat berbeda. Pada stres kronik akan terjadi peningkatan sekresi glukokortikoid yang disertai dengan penurunan leptin di dalam sirkulasi yang akan menyebabkan inhibisi propiomelanokortin dan aktivasi neuron neuropeptida $\mathrm{Y}$ di nukleus arkuata sehingga meningkatkan asupan makanan dan bobot badan. Selain keadaan itu, peningkatan glukokortikoid juga mengaktivasi lipoprotein lipase yang memfasilitasi deposisi lemak sehingga mengakibatkan akumulasi lemak, terutama di daerah abdomen. ${ }^{14}$

Kelompok tikus yang mendapat perlakuan berbagai model stres kronik mempunyai jumlah sel piramidal CA3 hipokampus yang lebih rendah bila dibandingkan dengan kelompok kontrol, dan model stres imobilisasi memiliki jumlah sel piramidal CA3 hipokampus yang paling rendah secara signifikan dibandingkan dengan kelompok kontrol. Keadaan ini karena stres imobilisasi adalah suatu stressor kompleks yang menyangkut dimensi stres psikologis, fisik, dan sosial serta berbeda dari PSD yang merupakan stressor fisik dan psikologis ataupun footshock yang hanya mewakili stressor fisik. ${ }^{7}$

Stres jangka panjang dapat mengakibatkan kehilangan neuron piramidal, antar lain stres 


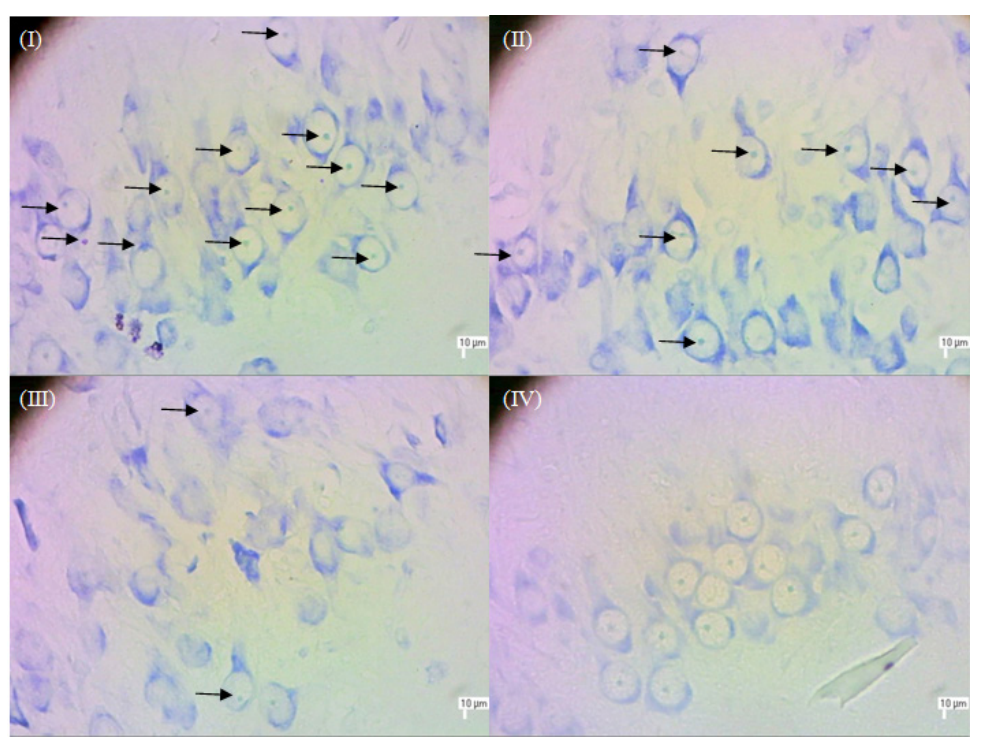

\section{Gambar 1 Jumlah Sel Piramidal CA3 Hipokampus $(\rightarrow=$ Inti Sel) Pewarnaan: Toluidine-blue. Perbesaran 400x \\ Keterangan: (I) kontrol, (II) PSD, (III) imobilisasi, (IV) footshock}

imobilisasi kronik selama 10 hari (2 jam per hari) menginduksi atrofi dendrit dan percabangan neuron piramidal CA3 hipokampus. ${ }^{15}$ Stres sosial kronik menyebabkan atrofi dendrit yang berujung pada kematian neuron. Stres imobilisasi selama 4 minggu pada tikus (3 kali per hari selama 30 menit) menyebabkan depresi akut yang dapat menurunkan volume hipokampus yang terlihat dari penurunan kepadatan neuron. ${ }^{16}$ Stres PSD kronik pada tikus jantan Sprague-dawley dapat menurunkan transmisi sinaps dan potensiasi jangka panjang yang berkaitan dengan proses ingatan pada CA1 hipokampus. ${ }^{5}$ Pengurangan waktu tidur juga menyebabkan stres oksidatif dan mengganggu proses belajar serta memori. ${ }^{17}$ Stres psikologik, termasuk PSD dapat membangkitkan aktivitas lipid peroksidase pada otak tikus. ${ }^{18}$ Mencit yang diberi stressor fisik meningkatkan indeks apoptosis neuron hipokampus regio CA3, perubahan fungsi, dan struktur hipokampus melalui peran kortisol dan interleukin-6 (IL-6) plasma.

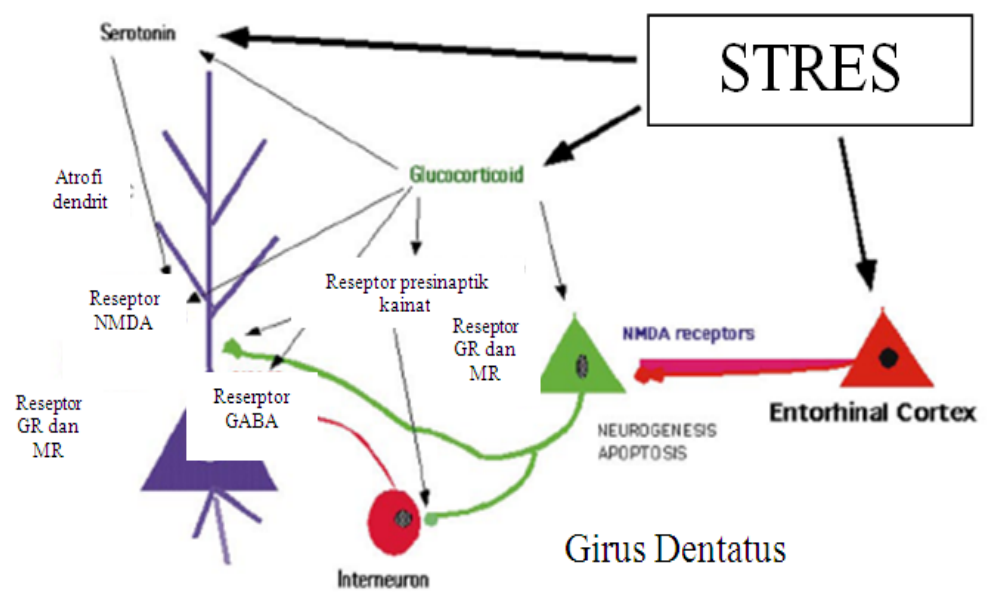

CA3

Gambar 2 Pengaruh Stres pada CA3 Hipokampus

Sumber: Taliaz dkk. ${ }^{4}$ 
Penurunan jumlah sel-sel piramidal CA3 hipokampus dapat disebabkan oleh karena stressor yang akan merangsang hipotalamus melepaskan corticotropin releasing hormone (CRH) dan arginine vasopressin (AVP) yang mengakibatkan hipofisis anterior melepaskan adenocorticotropic hormone (ACTH) yang merangsang korteks adrenal melepaskan glukokortikoid. Mekanisme atrofi apikal dendrit neuron sel piramidal CA3 hipokampus melibatkan glukokortikoid meliputi proses neurokimia peningkatkan ekspresi dan ikatan reseptor subunit NMDA (N-metil-Daspartat), peningkatan glutamat ekstrasel, 5HT turnover, induksi reseptor presinaps kainat pada mossy fiber terminal, mengganggu ekspresi reseptor subunit GABA (gamma-aminobutyric acid), dan menurunkan ekspresi reseptor inhibisi 5HT1 (5-hidroksitriptamin 1) (Gambar 2). ${ }^{4}$

Mekanisme glukokortikoid yang merusak hipokampus diawali glutamat yang merupakan neurotransmitter utama yang paling aktif di hipokampus dan banyak dikeluarkan saat stres. Konsentrasi glukokortikoid tinggi yang bekerja pada reseptor glukokortikoid akan meningkatkan keterlibatan akumulasi glutamat yang berlebihan di sinaps, dengan akibatnya glutamat meracuni hipokampus. Pelepasan glutamat juga meningkat karena aktivitas reseptor presinaptik yang terdapat pada mossy fibre terminal (MFT) dari lapisan lusidum hipokampus bersama-sama mitokondria, memicu perbanyakan vesikel. ${ }^{4}$ Neurotransmitter eksitatori glutamat menstimulasi produksi nitrit oxide (NO) yang meningkat, mengakibatkan efek toksik melalui interaksi cepat dengan superoksida anion, membentuk peroksinitrim sebagai spesies reaktif yang menyebabkan atrofi neuron $\mathrm{CA} 3{ }^{4}{ }^{4}$

Reseptor tipe II glukokortikoid yang banyak di hipokampus, rentan terhadap pengaruh stres dengan menekan long-term potentiation (LTP) dan menghambat transpor glukosa di hipokampus sehingga menurunkan ATP basal. ${ }^{4}$ Glukokortikoid yang meningkat menyebabkan disrupsi metabolik, yaitu menghambat ambilan glukosa sehingga penurunan kadarnya menyebabkan peningkatan glutamat di celah ekstraseluler yang selanjutnya mengaktivasi reseptor NMDA sebagai induktor perubahan degeneratif, khususnya di apoptosis. Produksi $\mathrm{Ca}^{2+}$-sitosol yang merupakan efek samping aktivitas glutamat yang berlebihan, akan menyebabkan overaktivitas $\mathrm{Ca}^{2+}$-dependent enzyme sehingga terjadi perubahan degeneratif dan pembangkitan radikal $\mathrm{O}_{2}{ }^{18}$

Radikal bebas yang berlebihan mengakibatkan stres oksidatif yang menghasilkan reaksi lipid peroksidase yang berbahaya pada otak karena otak tidak diperkaya bahan-bahan protektif seperti enzim ataupun senyawa antioksidan sehingga ketika iskemik atau hipoksia, akan diproduksi radikal bebas yang berujung pada kematian sel (apoptosis). ${ }^{4}$

Simpulan penelitian ini adalah jumlah sel pada piramidal CA3 hipokampus tikus putih jantan paling rendah pada stres kerja model imobilisasi kronik dibandingkan dengan ketiga model stres kerja lainnya dikarenakan stres imobilisasi adalah suatu stresor kompleks yang terdiri atas aspek psikologis, fisik, dan sosial.

\section{Ucapan Terima Kasih}

Ucapakan terima kasih disampaikan kepada Direktorat Jenderal Pendidikan Tinggi (DIKTI) Kementerian Pendidikan dan Kebudayaan atas dana hibah skema Hibah Fundamental tahun 2012, Kepala Laboratorium Fisiologi dan Patologi Anatomi (PA) Fakultas Kedokteran Universitas Gadjah Mada serta Kepala Laboratorium Hewan Coba Fakultas Kedokteran dan Ilmu Kesehatan Universitas Jenderal Soedirman sebagai tempat penelitian.

\section{Daftar Pustaka}

1. Duvernoy HM. The human hippocampus functional anatomy, vascularization, and serial sections with MR. Edisi ke-3. New York: Springer-Verlag Berlin Hiedelborg; 2005.

2. Standring S. Gray's anatomy the anatomcal basis of clinical practice. Edisi ke-39. Philadelphia: Elsevier Churchill Livingstone; 2005.

3. Suparno. Pengaruh stresor fisik terhadap distribusi sert dan indeks apoptosis neuron hipokampus, SERT distribusi TNF-A gaster tikus, dengan mediasi kortisol dan Il-6. Berk Penel Hayati. 2008;14:79-90.

4. Taliaz DL, Assaf G, Roman H, Sharon C, Alon Z, Abraham. Resilience to chronic stress is mediated by hippocampal brainderived neurotrophic factor. J Neurosci. 2011;31(12):4475-83.

5. Conrad CD. Chronic stress-induced hippocampal vulnerability: the glucocorticoid vulnerability hypothesis. Rev Neurosci. 2008;19(6):395-411.

6. Vogel FR. Stress in the workplace: the phenomenon, some key correlates and problem solving approach [Disertasi]. Pretoria: University or Pretoria; 2006.

7. Arjadi F, Soejono SK, Pangestu M.. Pengaruh berbagai model stress terhadap reproduksi tikus putih jantan (Rattus norvegicus) (Kajian hormonal, densitas ekspresi reseptor 
CYP19 dan glukokortikoid serta fungsi testis) [Laporan penelitian]. Purwokerto: Universitas Jenderal Soedirman; 2012.

8. Ravassard PP, Bastien C, Jean-Christophe CM, Perez CS, Blachon G, Nadine C, dkk. Paradoxical (REM) sleep deprivation causes a large and rapidly reversible decrease in longterm potentiation, synaptic transmission, glutamate receptor protein levels, and ERK/ MAPK activation in the dorsal hippocampus. Sleep. 2009;32(2):227-40.

9. Nelson A, Gilbert S. The Harvard medical school guide to achieving optimal memory. New York: McGraw-Hill; 2005.

10. Machado RB, Hipolide DC, Benedito-Silva AA, Tufik S. Sleep deprivation induced by modified multiple platform technique: quantification of sleep loss and recovery. Brain Res. 2004;1004:45-51.

11. Andersen ML, Martins PJ, D'Almeida, Bignotto M, Tufik S. Endocrinological and catecholaminergic alterations during sleep deprivation and recovery in male rats. J Sleep Res. 2005; 14:83-90.

12. Kvetnansky, McCarty R. Stress imobilization. Endocrinology. 2007;2:503-6.
13. Costa MV, Ana CCM, Larissa CM, Euclides,M. Fluoxetine effects on paradoxical sleep deprivation. Neurobiology. 2010;73(2): 107-12.

14. Torres S, Nowson C. Relationship between stress, eating behaviour and obesity. Nutritism. 2007;23(11-12):887-94.

15. Lajtha A, Blaustein JD. Handbook of neurochemistry and molecular neurobiology Edisi ke-3. USA: Springer; 2007.

16. Nasir N, Khan AA. Effects of stress-induced acute depression and antidepressant drugs on CA3 region of hippocampus albino rats. Curr Neurobiol. 2011;2(1):31-4.

17. Alzoubi KH, Khabour OF, Rashid BA, Damaj IM, Salah HA. The neuroprotective effect of vitamin $\mathrm{E}$ on chronic sleep deprivationinduced memory impairment: the role of oxidative stress. Behav Brain Res. 2012;226: 205-10.

18. Wiyono N, Soedjono SK, Harijadi. Hubungan antara tebal lamina pyramidalis CA1 hippocampus dengan memori kerja pada tikus (Rattus norvegicus) pascastres kronik. J Anat Indo. 2007;01(03):104-11. 